IJMS 17 (2), 1-26 (2010)

\title{
MICROFINANCE AND MECHANISM DESIGN: THE ROLE OF JOINT LIABILITY AND CROSS-REPORTING
}

\author{
ZULKEFLY ABDUL KARIM \\ Faculty of Economic and Business \\ Universiti Kebangsaan Malaysia
}

\begin{abstract}
Since the establishment of Grameen Bank in 1976 by Professor Muhammad Yunus $^{1}$, many economists have studied extensively, either theoretically or empirically, the success of the Grameen Bank in eradicating the poverty problem in Bangladesh. Therefore, this paper aims to apply the mechanism design theory in microfinance by examining the role of joint liability and crossreporting mechanism in the loan contract which is designed by microfinance lender. In doing so, this study simplified the joint liability mechanism proposed by Ghatak $(1999,2000)$ and cross-reporting mechanism by Rai and Sjostrom (2004). Based on the joint-liability mechanism, it is clearly stated that the microfinance lender can minimise or avoid the adverse selection problem in the credit market through peer selection and peer screening. In the meantime, the joint liability mechanism is better than individual lending in terms of increasing the social welfare among the poor borrower, charging lower interest rates, and generating high repayment rates. In contrast, Rai and Sjostrom (2004) argued that joint liability alone is not enough to efficiently induce borrowers to help each other. Indeed, the cross-reporting mechanism is also important for lenders in order to minimise the problem of asymmetric information in the credit market. The cross-reporting mechanism is also efficient because it can influence the borrower to be truthful-telling about the state of the project and subsequently can minimise the deadweight loss (punishment) among the borrowers. In comparison, without crossreporting, the lending mechanism is inefficient because the borrower will be imposed harsh punishment from the bank and the bank can undertake auditing or verify the state of the project and punish accordingly.
\end{abstract}

Keywords: Microfinance; mechanism design; joint liability; cross-reporting. 


\begin{abstract}
Abstrak
Sejak penubuhan Bank Grameen pada tahun 1976 oleh Profesor Muhammad Yunus, banyak ahli ekonomi telah mengkaji secara ekstensif sama ada kajian secara teori atau empirikal terhadap kejayaan Bank Grameen dalam mengatasi masalah kemiskinan di Bangladesh. Justeru, kajian ini bertujuan untuk mengaplikasikan teori reka bentuk mekanisme (mechanism design theory) dalam bidang mikro kewangan dengan memeriksa peranan mekanisme liabiliti bersama (joint liability mechanism) dan mekanisme laporan bersilang (cross-reporting mechanism) dalam kontrak pinjaman yang direka bentuk oleh pemberi pinjaman mikro kewangan. Kajian ini telah mengubah suai model mekanisme liabiliti bersama oleh Ghatak (1999; 2000) dan mekanisme laporan bersilang oleh Rai dan Sjostrom (2004). Berasaskan kepada mekanisme liabiliti bersama, pemberi pinjaman mikro kewangan boleh meminimumkan atau mengelak masalah pilihan kurang baik (adverse selection) dalam pasaran kredit melalui pilihan sesama anggota (peer selection) dan penapisan sesama anggota (peer screening). Mekanisme pinjaman liabiliti bersama juga lebih baik berbanding dengan pinjaman individu daripada aspek meningkatkan kebajikan sosial dalam kalangan peminjam miskin, mengenakan caj kadar bunga yang lebih rendah dan menjana kadar pembayaran balik pinjaman yang lebih tinggi. Sebaliknya, Rai dan Sjostrom (2004) berpendapat mekanisme liabiliti bersama sahaja tidak mencukupi untuk meningkatkan kecekapan dalam kalangan peminjam bagi memberi bantuan antara satu sama lain. Maka, mekanisme laporan bersilang juga sangat penting kepada pemberi pinjaman untuk meminimumkan masalah maklumat tak simetri dalam pasaran kredit. Melalui mekanisme laporan bersilang, ia boleh mempengaruhi peminjam untuk memberikan maklumat secara jujur (truthful-telling) mengenai situasi sesuatu projek dan kemudiannya boleh meminimumkan kerugian luput dalam kalangan peminjam. Sebagai perbandingan, tanpa mekanisme laporan bersilang, mekanisme pinjaman tidak cekap kerana peminjam akan dikenakan hukuman yang lebih tinggi (harsh-punishment) daripada bank dan pihak bank juga akan menjalankan pengauditan atau menentusahkan keadaan sesuatu projek dan mengenakan hukuman yang sewajarnya kepada peminjam.
\end{abstract}

Kata kunci: Mikro kewangan; reka bentuk mekanisme; liabiliti bersama; laporan bersilang.

\title{
Introduction
}

There is no doubt that the microfinance institutions (henceforth MFIs) ${ }^{2}$ play a vital role in alleviating the poverty problem and fostering

2 IJMS 17 (2), 1-26 (2010) 
social change in less-developed countries. Traditionally, a lack of collateral is a major obstacle for poor people in accessing credit from conventional banks. Meanwhile, MFIs have eradicated this problem as now the poor people can access credit without any collateral conditions. Indeed, MFIs also bring a solution to the credit market failures that stem from poor information, high transaction cost, and difficulties enforcing contract. Therefore, the role of MFIs is becoming increasingly more important in granting small loans to poor people in order to start their businesses. According to Armendariz and Morduch (2007), the traditional commercial banks avoid loaning to poor people because the loans are small and the profits are typically hard to find, and the lending is too risky to the banks because the borrowers are to poor to provide the collateral. In addition, the establishment of MFIs is also crucial for poor people in order to avoid loans from informal money lenders (loan sharks) who charge higher interest rates (usurious rates).

Even though giving credit to the poor is questionable, the experience from the Grameen Bank has reported high rates of repayment, often greater than $90 \%$. For instance, a study conducted by Morduch (1999), in the 10 years of the establishment of the Grameen Bank, the average loan grew from US \$ 10 million to US \$ 271 million, and membership expanded more than 12-fold to include 2.06 million members in 1996. For this decade, the Grameen Bank reports an average default rate of only $7.8 \%$. In fact, this rate is still impressive relative to the performance of other government development banks. The success of the Grameen Bank has been replicated all over the world ${ }^{3}$. Many economists believed that the Grameen lending methodology has been successful because of the group lending or joint liability mechanism ${ }^{4}$, which induced the borrowers to provide mutual assistance in hard times (Besley \& Coate, 1995; \& Yunus, 1999). Meanwhile, Rai and Sjostrom (2004) argued that joint liability alone is not enough to efficiently induce borrowers to help each other. In fact, it is also necessary for each borrower to report the state of the project to each other (cross-reporting). This means that both lending mechanisms either joint liability or cross-reporting complement each other in making sure that the borrowers provide mutual assistance, and subsequently can avoid the risk of default.

The objective of this paper is to apply the mechanism design theory to a loan contract that is designed by the non-profit organisation bank or MFIs, and targeted at poor borrowers who possess the private information. Therefore, this essay is organised into five sections. Section 2 will comprise of a literature review and Section 3 explains the 
Grameen Bank lending methodology. The two lending mechanisms, namely the joint liability and cross reporting will be discussed in Section 4, and finally Section 5 summarises and concludes.

\section{Literature Review ${ }^{5}$ :Microfinance and Grameen Bank ${ }^{6}$}

Since the establishment of Grameen Bank by Professor Muhammad Yunus in 1976, many economists have studied extensively, either theoretically or empirically, the success of the Grameen Bank in eradicating the poverty problem in Bangladesh. ${ }^{7}$ For instance, many theoretical ${ }^{8}$ studies have examined the idea of group lending mechanism (joint liability) in the asymmetric information framework. According to the theory, there are four problems in the credit market namely; adverse selection, moral hazard, costly state verification, and enforcement. These problems exist because the lender (principal) is unable to observe the actions or agent types. Therefore, the bank (lender) has to design an efficient lending mechanism in order to minimise or avoid the asymmetric information problems in the group-lending contract.

For instance, there are some studies which stated that the joint liability mechanism can help to overcome the adverse selection problem (Ghatak, 1999, 2000; Ghatak \& Guinnane, 1999; Laffont \& N'Guessan, 2000; Armendariz \& Gollier, 2000). Other studies by Stiglitz (1990), Banerjee, Besley, and Guinnane (1994), and Conning (2000) have discussed comprehensively the role of joint liability in solving the moral hazard problem. According to Ghatak and Guinnane (1999) ${ }^{9}$, there are two reasons why the joint liability contract performs well, firstly, the perfect information among the community members, and secondly, the fact that poor people may be able to impose powerful non-financial sanctions at low cost. Armendariz and Morduch (2000), and Bond and Krisnamurthy (2002) concluded that the success of Grameen Bank is influenced by direct monitoring, a regular repayment schedule and non-refinancing threats among the group members.

There are several studies in microfinance that use the game theory and mechanism design approach; for example, Besley and Coate (1995), and Rai and Sjostrom (2004)..$^{10}$ Besley and Coate (1995) setup a "repayment-game" and found that group lending have both positive and negative effects on repayment rates when compared with individual loans. Any group member with a high project return can pay off the loan of a peer whose project is unsuccessful. This is a kind

4 IJMS 17 (2), 1-26 (2010) 
of insurance for the borrowers. The group lending can also harness social collateral and mitigate the negative effect. Rai and Sjostrom (2004), by using the mechanism design approach, argued that cross reporting could improve the performance and efficiency. They stated that cross reporting is essential in extracting the information on the state of the borrower's project without undertaking auditing from the bank. The borrowers are assumed to perfectly observe each other's outcomes. Once the project is realised, the borrower can make a decision on the repayment and then report it to the bank along with information about the other borrower's project. Consequently, under this mechanism, it clearly shows that the borrowers always report the truth about the other borrowers to the bank. Thus, the bank does not ever punish the borrower in equilibrium.

\section{Grameen Bank and the Loan Process: Group-Lending Methodology}

The Grameen Bank ${ }^{11}$ in Bangladesh is the pioneer of group-based lending. Its main characteristic is providing loans of a small amount (an average of around US \$ 120 per loan or less, repaid at weekly meetings and has to fully repaid within one year) to poor people (particularly the women) for a self-employed project (poultry, paddy husking, handloom weaving, grocery or tea shop, and dairy farming). At the Grameen Bank, borrowers are grouped voluntarily which consist of five members each and are formed voluntarily without any intervention or pressure from the bank. Five-member groups are considered an optimum size to maximise the benefits of "peer monitoring" and can also avoid the "free rider" problem if the group size is too large (Armendariz \& Morduch, 2007). The bank designed a mechanism in which two members of each five-person group would receive their loan first. If, the entire instalment is paid on schedule, the cycle of the loans continue to the other two members in four to six weeks later, and finally after another four or six weeks, the bank will provide the loan to the group chairperson. ${ }^{12}$

Under the group lending methodology, all group members are jointly liable. This means that all group members are held responsible for loan repayment despite the loans being made to individuals. According to these rules, if one member defaults and fellow group members also do not pay the debt, all in the group are denied the subsequent loans. Therefore, this mechanism gives the borrowers an incentive to repay the loans promptly, to monitor their group members (peer monitoring), and to encourage the borrowers to select responsible 
partners when forming the group (peer selection). This can minimise the incidence of default because the borrowers would make sure that their peers have put sufficient effort into the particular project.

After the formation of the group, within the first two to three weeks, all members of the group are required to make small deposits to the bank. The Grameen Bank employees also provide training to the groups. In the meantime, the first two group members are initially issued credit. The group is then observed for a month or two to ensure that the required weekly repayment (regularly scheduled repayment) is paid and the financial and social discipline of the group is maintained.

Another interesting feature about the Grameen Bank lending methodology is the establishment of a centre. Since the groups are eventually tied together, the centres play a vital role to the borrowers for sharing the information, exchange of ideas, and for solving any problems arising in the projects. Specifically, centres comprises five to eight groups plus a secretary and they are led by an elected chairperson, known as a chief. It is the responsibility of the chief to conduct the centre meetings and monitor loan utilisation on a daily basis along with the group chairpersons. Grameen Bank employees are available to assist the centres in their activities and they typically attend the weekly meetings where the group performances are openly discussed. During these meetings, each group is required to submit a report to the chairperson and then the chairperson gives the report the Grameen Bank employee. In addition, the individual members of a group are allowed to individually select and identify their activities for which the loans will be provided. The selections are then discussed at the group and centre meetings, where the individual members can guide one another under the direct supervision of a Grameen Bank employee.

\section{The Model}

\section{Economic Environment}

In this study, the principal-agent framework was used in analysing how the bank designs the loan contract to the poor borrowers. The bank is a mechanism designer (the principal) and the agent is the poor borrower who possesses the private or hidden information. ${ }^{13}$ In this model, we assumed that both bank and borrower are risk neutral. The bank cannot observe the borrower types but the borrowers can

6 IJMS 17 (2), 1-26 (2010) 
observe each other's types. The impoverished borrower $(i)$ has no wealth which the reservation wage (utility) is $\bar{U}$. Meanwhile, the bank has the opportunity cost of capital $(\rho)$ which lends in a competitive loan market and collateral cannot be used because of the poverty of the borrowers.

Suppose there are two type of borrowers in an economy; good-risk (safe borrower or $s$ ) and bad-risk (risky borrower or $r$ ) or $i \in\{s, r\}$. A project undertaken by the borrower of type $i$, produces an output valued at $x_{i}$ when it succeeds and 0 when it fails or $x \in\left\{x_{i}, 0\right\}$. In addition, the probability of the project succeeding is contingent on the borrower types. The project succeeds with probability $p_{i}$ and fails with probability $1-p_{i}$. Therefore, the project that risky and safe types undertake succeed with probability $p_{r}$ and $p_{s}$ respectively, where the risky type succeeds less often than the safe type or $0<p_{r}<p_{s}<1$ where $p_{r}+p_{s} \geq 1$. The proportion of risky type and safe type is $\theta$ and $1-\theta$ respectively in the population. The principal (bank) knows the fraction of each type in the population, but is unable to determine which specific investors are of which type. Since the lender cannot observe the output level, it can impose a punishment on borrowers who do not repay or strategically default. There are two components of loan contract namely individual liability component (interest rates) or $R$, and a joint liability component or $Q$. It is assumed that there is no moral hazard, costly state verification, and enforcement problem in the loan contract. Therefore, the lender is only concerned with the adverse selection problem ${ }^{14}$ in designing the loan contract. This problem occurs before the contractual arrangements where the bank cannot easily determine which customers are likely to be more risky than others. If lenders could differentiate by risk type, they could discriminate the interest rates to the different types of borrowers. Nevertheless, with poor information, options are limited. Thus, in order to discuss a simple adverse selection model in the individual liability and joint liability contract, the adverse selection model proposed by Ghatak $(1999,2000)$ was simplified.

The borrowers are also required to report (cross-reporting) the state of the project to the lender. In village economies, the borrowers often share information about each other in terms of outputs, effort level, or types but the bank does not possess this information. Cross reporting allows the bank to gather information on a problem borrower's output by soliciting reports from her peers and showing leniency when all

IJMS 17 (2), 1-26 (2010) 7 
reports agree with each other. Under this mechanism, the bank must credibly commit itself to a system of reward for truth telling from the borrower and the bank must itself check on its borrowers monitoring activities. If a group member is lying about the state of a project, the bank can impose a punishment such as denial of future credit, imposed additional interest penalty, or social sanctions. Therefore, the model proposed by Rai and Sjostrom (2004) was simplified in order to discuss the role of cross reporting in the loan contract.

\section{Individual Loan Contract}

Under individual lending (without joint liability), the borrower $i$ 's expected payoff when the interest rates is $R$, is given by;

$E U_{i}(R)=p_{i} x_{i}-R p_{i}=p_{i}\left(x_{i}-R\right), i=r, s$

It is also assumed that the borrower has a socially viable project that is the expected output of the project exceeds the opportunity cost of capital and reservation wages as follows;

$p_{i} x_{i} \geq \rho+\bar{U}$

Equation (2) can also be rewritten as a participation constraint or individual rationality constraint, as follows;

$p_{i} x-\rho \geq \bar{U}=p_{i}\left(x_{i}-R_{i}\right) \geq \bar{U}$

From equation (3), in order to ensure that the agent participates in the loan contract, the principal must ensure that the agent gets at least their reservation wage (utility) or $\bar{U}$. Besides the participation constraint (PC), the lender has to ensure that the individual loan contract also satisfies the incentive compatibility constraint (ICC) such as;

$U_{r}\left(R_{r}\right) \geq U_{r}\left(R_{s}\right)$

$U_{s}\left(R_{s}\right) \geq U_{s}\left(R_{r}\right)$

Equation (4a) states that the risky type weakly prefers taking a loan contract at interest rates $R_{r}$ than a contract at interest rates $R_{s}$,

8 IJMS 17 (2), 1-26 (2010) 
meanwhile equation (4b) is satisfied when the safe type weakly prefers taking a contract at interest rates $R_{s}$ than a contract an interest rates $R_{r}$.

Without private information (complete information), the bank lends to the borrower at risk adjusted interest rates in a competitive loan market and can also discriminate the interest rates according to the agent types (separating equilibrium). Therefore, since the bank is a non-profit organisation and operating in a competitive loan market, the lender zero-profit constraint (L-ZPC) is hold such as $\rho=p_{i} R_{i}$. By solving the lender zero-profit constraint (L-ZPC), the bank would charge the interest rates such as;

$$
R_{i}=\frac{\rho}{p_{i}}, \text { where } i=r, s
$$

From equation (5), with complete information the principal/designer will lend the safe type with interest rates $R_{s}=\frac{\rho}{p_{s}}$ and the risky type $R_{r}=\frac{\rho}{p_{r}}$. Since, $p_{r}<p_{s}$ the risky type succeeds and repays back less often, then the bank can discriminate by charging the risky type with higher interest rates than safe type, or $R_{r}>R_{s}$.

With private information (incomplete information), the principal is unable to observe the agent types. Therefore, the bank is unable to discriminate against the risky borrowers and the interest rates become exceedingly high. In this situation, the bank will impose the same interest rates among the borrowers (pooling equilibrium). In fact, the risky types are subsidised by the safe type as the safe type pay more interest rates in order to ensure that the lender would break even. Consequently, the high interest rates in turn will drive worth borrowers (safe borrowers) out in the credit market.

Since the repayment rate on the particular loan is the proportion of borrowers that repay back, if the principal (bank) only lends to the risky type, the repayment rate is $p_{r}$ and similarly if the bank only lends to safe types, the repayment rate is $p_{s}$. In reality, the bank usually lends to both types, therefore the average repayment rate is;

$\bar{p}=\theta p_{r}+(1-\theta) p_{s}$ 
Therefore, under private information (imperfect information) the principal will charge a unique (single) interest rates, as follows;

$R=\frac{\rho}{\bar{p}}=\frac{\rho}{\theta p_{r}+(1-\theta) p_{s}}$

According to Stiglitz and Weiss (1981), under imperfect information, both types of the project have the same expected return as the following;

$p_{s} x_{s}=p_{r} x_{r}=\hat{x}$

Therefore, the expected payoff of safe type is less than the expected payoff of risky type, as follows;

$$
\hat{x}-R p_{s}<\hat{x}-R p_{r} \quad \text { or } \hat{x}-\left(\frac{\rho}{\bar{p}}\right) p_{s}<\hat{x}-\left(\frac{\rho}{\bar{p}}\right) p_{r}
$$

\section{Joint Liability Contract}

Group lending with joint liability ${ }^{15}$ can help to overcome the problem of adverse selection in the individual lending. This mechanism can improve inefficiency by enabling the safe types back in the credit market. In fact, it also leads to an improvement in reimbursement rates, a reduction of the interest rates, and an increase in social welfare (Ghatak, 1999). In the process of group formation, group members are expected to screen each other. Through peer selection and peer screening the borrower would try to prevent irresponsible and credit risky individuals from joining their group.

Suppose that the mechanism designer (principal) offers a joint liability contract, such as $\{R, Q\}^{16}$. If the agents accept the contract, they will pay the specified interest rates $R$ if the project succeeds, but if the peer fails, the borrower is also required to pay an additional joint liability component $Q$ (jointly liable). Therefore, the expected payoff of the borrower type $i$ when the partner is type $j$ in a joint-liability contract $\{R, Q\}$ is given by;

10 IJMS 17 (2), 1-26 (2010) 


$$
\begin{aligned}
& E U_{i j}(R, Q)=p_{i} p_{j}\left(x_{i}-R\right)+p_{i}\left(1-p_{j}\right)\left(x_{i}-R-Q\right) \\
& \left.=p_{i} p_{j} x_{i}-p_{i} p_{j} R+p_{i} \mid x_{i}-R-Q-p_{j} x_{i}+p_{j} R+p_{j} Q\right\rfloor \\
& =p_{i} p_{j} x_{i}-p_{i} p_{j} R+p_{i} x_{i}-p_{i} R-p_{i} Q-p_{i} p_{j} x_{i}+p_{i} p_{j} R+p_{i} p_{j} Q \\
& =p_{i} x_{i}-p_{i} R-p_{i} Q+p_{i} p_{j} Q \\
& =p_{i}\left(x_{i}-R\right)-p_{i} Q\left(1-p_{j}\right)
\end{aligned}
$$

From equation (10), given the joint-liability loan contract $\{R, Q\}$ on offer, the mechanism designer requires that the borrowers self-select (peer selection) into the group of two before the bank approves the loan. According to Ghatak $(1999,2000)$ under the group lending, it can create a mechanism where the borrower has two strategies to match with their group partner. Firstly, positive assortative matching implies that the borrowers match with their own type and thus the group is homogenous in their composition. This means that the groups would either have both safe types and both risky types. Secondly, negative assortative matching is where the borrowers match with other types and thus the group is heterogeneous in its composition. This implies that each group has one safe type and one risky type.

It is true that based on the evidence due to the joint liability payment $Q$, everyone wants the safest partner in the loan contract. This is because, the safer the partner, the lower probability of incurring the joint liability payment due to partner failure. The question is, what is the benefit to the risky type by taking the safe partner in the group and what is the loss to the safe type by taking a risky partner in the group? Equations (11)-(12) can answer this question.

$$
\begin{aligned}
& E U_{r s}(R, Q)-E U_{r r}(R, Q)=p_{r}\left(p_{s}-p_{r}\right) Q \\
& E U_{s s}(R, Q)-E U_{s r}(R, Q)=p_{s}\left(p_{s}-p_{r}\right) Q
\end{aligned}
$$

Equation (11) refers to the net expected payoff to the risky type from pairing with the safe type instead of with the risky type and equation (12) is the net expected loss to the safe type from pairing with the risky type instead of with the safe type. From equation (11) and (12), we know that,

$$
\begin{aligned}
& E U_{s s}(R, Q)-E U_{s r}(R, Q)>E U_{r s}(R, Q)-E U_{r r}(R, Q) \text { or } \\
& p_{s}\left(p_{s}-p_{r}\right) Q>p_{r}\left(p_{s}-p_{r}\right) Q
\end{aligned}
$$


From equation (13), by comparing both equations, it is clear that the safe type's loss exceeds the risky type's gain. Therefore, under joint liability contract, it leads to positive assortative matching where a safe type pairs up with another safe type and the risky type pairs with another risky type. Consequently, by rearranging equation (13), the positive assortative matching will lead a socially optimal matching that maximises the aggregate expected payoffs of the borrowers over all possible matches such as;

$E U_{s s}(R, Q)+E U_{r r}(R, Q)>E U_{r s}(R, Q)+E U_{s r}(R, Q)$

By assuming positive assortative matching ${ }^{17}$, the bank can design two types of loan contract $\left\{R_{r}, Q_{r}\right\}$ and $\left\{R_{s}, Q_{s}\right\}$. Since the bank is a zero profit organisation, it offers a group contract $\left\{R_{r}, Q_{r}\right\}$ and $\left\{R_{s}, Q_{s}\right\}$ which maximises a weighted average of the expected utilities of a representative borrower of each of the two possible types subject to several constraints. Hence, the mechanism designer problem can be expressed

$\operatorname{Max} V(R, Q)=\lambda U_{r r}\left(R_{r}, Q_{r}\right)+(1-\lambda) U_{s s}\left(R_{s}, Q_{s}\right)$

where $\lambda \in(0,1)$ may or may not depend on the size of particular type of borrower in the population, $\theta$.

subject to;

$$
\begin{aligned}
& R_{r} p_{r}+Q_{r}\left(1-p_{r}\right) p_{r} \geq \rho \\
& R_{s} p_{s}+Q_{s}\left(1-p_{s}\right) p_{s} \geq \rho \\
& U_{i i}\left(R_{i}, Q_{i}\right) \geq \bar{U}, \text { where } i=r, s \\
& x_{i} \geq R_{i}+Q_{i}, \text { where } i=r, s \\
& U_{r r}\left(R_{r}, Q_{r}\right) \geq U_{r r}\left(R_{s}, Q_{s}\right) \\
& U_{s s}\left(R_{s}, Q_{s}\right) \geq U_{s s}\left(R_{r}, Q_{r}\right)
\end{aligned}
$$


Equation (16) and (17) is the mechanism designer or the lender zeroprofit constraint $\left(L-Z P C_{i}\right)$ for the borrower type $i$ (risky type in equation (16) and safe type in equation [17]). Equation (18) is the participation constraint $\left(P C_{i}\right)$ or individual rationality constraint for type $i$, which stated that the agent must receive at least his reservation utility $\bar{U}$ in order to participate in the contract. Equation (19) is the limited liability constraint $\left(L L C_{i}\right)$ for type $i$ and equation (20) and (21) is the incentive compatibility constraint $\left(I C C_{i}\right)$ for group $i, i$.

The first order condition from equation (16) and (17) we get;

$\frac{d Q_{r}}{d R_{r}}=-\frac{1}{1-p_{r}}$ and $\frac{d Q_{s}}{d R_{s}}=-\frac{1}{1-p_{s}}$.

Both measure the slope of the indifferent curve among the risky and safe agents. Since $p_{s}>p_{r}$, and $p_{s}>p_{r}$, and $\left|-\frac{1}{1-p_{s}}\right|>\left|-\frac{1}{1-p_{r}}\right|$ the safe type's indifferent curve is steeper than the risky type's indifferent curve. Figure 1 shows that the optimal loan contract under pooling equilibrium can be determined at the point where the $L-Z P C_{s}$ and $L-Z P C_{r}$ cross each other, that is at point $\hat{E}$ (singlecrossing property), which the optimal interest rates and joint liability is $\{\hat{R}, \hat{Q}\}{ }^{18}$ respectively. Mathematically, by solving equation (16) and (17) with equality, for pooling equilibrium, explicitly we get;

$R_{r}=\frac{\rho-Q_{r}\left(1-p_{r}\right) p_{r}}{p_{r}}$

Since under pooling equilibrium, $Q_{r}=Q_{s}$ and $R_{r}=R_{s}$. By substituting (22) into (17), we get;

$$
\left(\frac{\rho-Q\left(1-p_{r}\right) p_{r}}{p_{r}}\right) p_{s}+Q\left(1-p_{s}\right) p_{s}=\rho
$$




$$
\begin{aligned}
& Q\left[\left(1-p_{s}\right) p_{s}-\frac{\left(1-p_{r}\right)}{p_{r}} p_{r} p_{s}\right]=\rho-\rho \frac{p_{s}}{p_{r}} \\
& Q\left[p_{s}-p_{s}^{2}-\left(p_{s}-p_{s} p_{r}\right)\right]=\frac{\rho p_{r}-\rho p_{s}}{p_{r}} \\
& Q=\frac{\rho\left(p_{r}-p_{s}\right)}{p_{r}\left(p_{s} p_{r}-p_{s}^{2}\right)}=\frac{\rho\left(p_{r}-p_{s}\right)}{p_{r} p_{s}\left(p_{r}-p_{s}\right)}=\frac{\rho}{p_{r} p_{s}}
\end{aligned}
$$

By plugging $Q=\frac{\rho}{p_{r} p_{s}}$ into equation (22), with equality we get;

$$
\begin{aligned}
& R=\frac{\rho-Q\left(1-p_{r}\right) p_{r}}{p_{r}}=\frac{\rho}{p_{r}}-\left(\frac{\rho}{p_{r} p_{s}}\right)\left(1-p_{r}\right) \\
& =\rho\left(\frac{p_{s}-\left(1-p_{r}\right)}{p_{r} p_{s}}\right)=\rho \frac{\left(p_{s}+p_{r}-1\right)}{p_{r} p_{s}}
\end{aligned}
$$

Therefore, under pooling contract, the optimal $\hat{R}$ and $\hat{Q}$ is;

$$
\hat{R}=\frac{\rho\left(p_{r}+p_{s}-1\right)}{\left(p_{r} p_{s}\right)} \quad \text { and } \quad \hat{Q}=\frac{\rho}{p_{r} p_{s}}
$$

By assuming positive assortative matching (separating equilibrium), the lender can separate the agent's types and can impose a different contract according to the group type of either safe or risky. Therefore, there are two outcomes of separating equilibrium for any joint liability contract $\{R, Q\}$. First, if $R_{s}<\hat{R}, Q_{s}>\hat{Q}$, then $U_{s s}\left(R_{s}, Q_{s}\right)>U_{r}\left(R_{s}, Q_{s}\right)$. Second, if $R_{r}>\hat{R}, Q_{r}<\hat{Q}$, then $U_{r r}\left(R_{r}, Q_{r}\right)>U_{s s}\left(R_{r}, C_{r}\right)$. These two outcomes show that the safe group prefers joint liability payment higher than $\hat{Q}$ and interest rates 14 IJMS 17 (2), 1-26 (2010) 
lower than $\hat{R}$. In comparison, the risky group prefers joint liability payments lower than $Q$ and the interest rates higher than $\hat{R}$. Therefore, with positive assortative matching, the lender can impose the price discrimination by charging each type at different interest rates $(R)$ and different joint liability $(Q)$. Indeed, joint liability lending can also increase repayment rates and allow the lender to lower the interest rates more than individual lending.

\section{A Numerical Example}

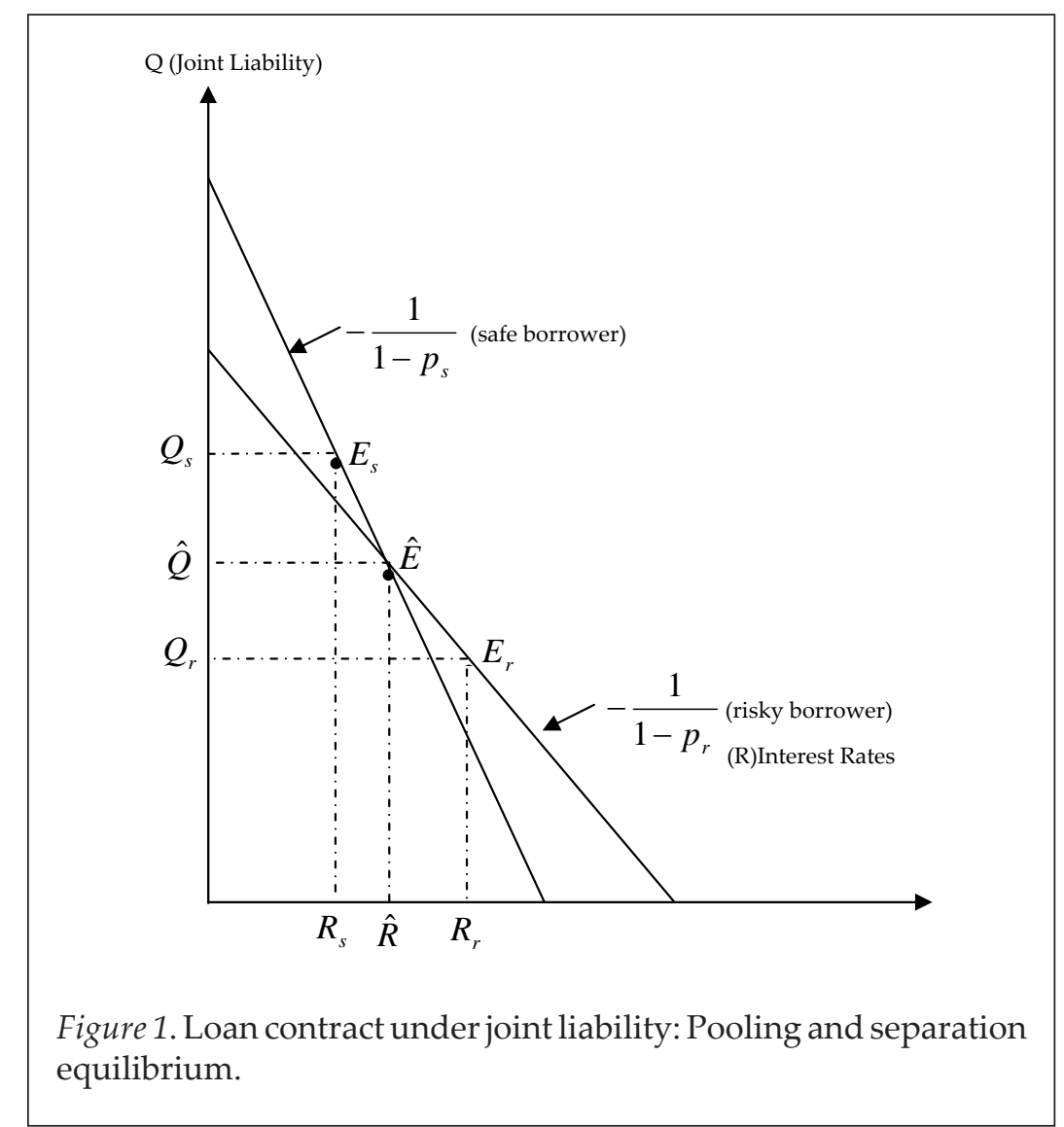

Table 1 gives a hypothetical example about the interest rates under individual lending and joint liability. It is clearly stated that, under separating equilibrium (without private information) the lender can discriminate the interest rates by charging higher interest rates to the 
risky type than the safe type. In contrast, with private information the lender cannot observe the borrower type and subsequently will charge a single interest rate (pooling equilibrium) that is $11.43 \%$. Thus, under pooling equilibrium, the safe type subsidises the risky type and subsequently the safe type will not participate in the credit market. In comparison, under joint liability with pooling equilibrium, the interest rates charged is $10 \%$, that is less than the interest rates under individual lending. Indeed, joint liability will bring back the safe type into the credit market.

Table 1

Interest Rates under Individual Lending and Joint Liability

The Economic Environment

- Lender's cost of capital $(\rho)=10 \%$ or 0.1

- Fraction of safe borrowers in the population $(\theta)=50 \%$ or 0.5

- Probability of success, $p_{r}=75 \%$ or 0.75 and $p_{s}=100 \%$ or 1.00

\begin{tabular}{c|c|c|c}
\hline \multicolumn{2}{c|}{ Individual Lending } & \multirow{2}{*}{$\begin{array}{c}\text { Joint Liability with } \\
\text { pooling equilibrium }\end{array}$} \\
\cline { 1 - 1 } \multicolumn{2}{c|}{ Separating Equilibrium } & Pooling Equilibrium & \\
\cline { 1 - 1 } Safe type & Risky type & & \\
$\left(R_{S}=\frac{\rho}{p_{S}}\right)$ & $\left(R_{r}=\frac{\rho}{p_{r}}\right)$ & $\left(R=\frac{\rho}{\bar{p}}\right)$ & $\hat{R}=\frac{\rho\left(p_{r}+p_{S}-1\right)}{\left(p_{r} p_{s}\right)}$ \\
\hline$\frac{0.1}{1.00}=10 \%$ & $\frac{0.1}{0.75}=13.33 \%$ & $\frac{0.1}{[0.5(0.75)+0.5(1)]}=11.43 \%$ & $\frac{0.1(0.75+1-1)}{(0.75)(1)}=10 \%$ \\
\hline
\end{tabular}

\section{Cross-Reporting Mechanism ${ }^{19}$}

Through cross-reporting, the successful borrower may be induced to help repay the loans of unsuccessful borrowers. For example, if group member $i$ fails to repay, borrower $j$ receives a harsh punishment only if borrower $i$ reports that borrower $j$ is withholding (lie) some output from the bank. This allows an unsuccessful borrower $i$ to pressure $j$ (the successful partner) to repay his loan. But if crossreporting reveal that borrower $j$ could not repay borrower $i$ 's portion, he will not be denied future access to loans. 
Cross-reporting can be related to repayment $\left(\varphi_{i}\right)$ from the borrower, refund $\left(\pi_{i}\right)$ and punishment $\left(z_{i}\right)$ from the bank, assuming we have two agents, $i \in\{1,2\}$ which produces output $x_{i}$. If borrower $i$ is successful, the gains is $m$, otherwise it is 0 , thus, $x_{i} \in\{0, m\}$. Therefore, there are four possible states for the project; $x=\left\{x_{1}, x_{2}\right\} \in[\{0,0\},\{0, m\},\{m, 0\},\{m, m\}]$. Suppose the agent $i$ decides to make the repayment rate $\left(\varphi_{i}\right)$ to the bank by amounts $\varphi_{i} \in[0, R, 2 R]$. If agent $i$ paid nothing, $\varphi_{i}=0$, then he/she can send a message $(\eta)^{20}$ to the bank that his peer partner, that is agent $j$ was successful. Thus, there are four possible strategies which agent $i$ can choose such as $s_{i}=[0,\{0, \eta\}, R, 2 R]$. If agents $i$ failed, she only can choose two strategies either 0 or $\{0, \eta\}$. Agent $i$ 's punishment $\left(z_{i}\right)$ is given by the matrix in Figure 2, where each row represents agent $i$ strategy and each column is strategy for agent $j, \gamma$ is the harsh punishment, and $\varepsilon$ is a small positive number. Therefore, the bank can impose the punishment such as $0 \leq z_{i} \leq \gamma$. For example, if agent $i$ chooses the strategies 0 and agent $j$ chooses $\{0, \eta\}$, then the punishment $\left(z_{i}\right)$ from the bank to agent $i$ is $z_{i}=2 R+\varepsilon$.

\begin{tabular}{|c|c|c|c|c|c|}
\hline \multirow{6}{*}{ Agent $i$ strategies } & \multicolumn{5}{|c|}{ Agent $j$ strategies } \\
\hline & & 0 & $\{0, \eta\}$ & $R$ & $2 R$ \\
\hline & 0 & $R$ & $2 R+\varepsilon$ & $2 R$ & $\gamma$ \\
\hline & $\{0, \eta\}$ & $\gamma$ & $\gamma$ & $\gamma$ & 0 \\
\hline & $R$ & 0 & $\gamma$ & 0 & 0 \\
\hline & $2 R$ & 0 & 0 & $\gamma$ & 0 \\
\hline
\end{tabular}

Agent $i^{\prime} s$ refund $\left(\pi_{i}\right)$ is given by the following matrix (Figure 3), where agent $i$ is a row player and agent $j$ is a column player. Suppose agent $i$ chooses strategy $2 R$ and agent $j$ chooses 0 . This means, agent $j$ brings no money to the bank and not report to the bank that agent $i$ is successful, while agent $i$ try to repay both loans. In this situation, the bank gives incentives or reward to the agent $i$ 
with a refund, and agent $j$ will be punished (for not reporting that agent $i$ is successful). Specifically, agent $i$ punishment is $z_{i}=0$, and her refund is $\pi_{i}=R+\varepsilon$, meanwhile agent $j$ punishment is $\gamma$ (harsh punishment).

\begin{tabular}{|c|c|c|c|c|c|}
\hline \multirow{6}{*}{ Agent $i$ strategies } & \multicolumn{5}{|c|}{ Agent $j$ strategies } \\
\hline & & 0 & $\{0, \eta\}$ & $R$ & $2 R$ \\
\hline & 0 & 0 & 0 & 0 & 0 \\
\hline & $\{0, \eta\}$ & 0 & 0 & 0 & 0 \\
\hline & $R$ & 0 & 0 & 0 & $R+\varepsilon$ \\
\hline & $2 R$ & $R+\varepsilon$ & 0 & 0 & 0 \\
\hline
\end{tabular}

Since $\varphi_{i}=2 R$, agent $i$ total repayment (net of the refund) plus punishment is

$$
\varphi_{i}-\pi_{i}+z_{i}=2 R-\{R+\varepsilon\}+0=2 R-R-\varepsilon=R-\varepsilon .
$$

Meanwhile, agent $j$ punishment is $z_{j}=\gamma$ and her refund is 0 . Therefore, agent $j$ total repayment plus punishment is $\varphi_{j}-\pi_{j}+z_{j}=0-\{0\}+\gamma=\gamma$. By using the fact that agent $i$ wants to minimise the total repayment rate $\varphi_{i}-\pi_{i}+z_{i}$, we can combine the fair $\left(\varphi_{i}-\pi_{i}+z_{i}, \varphi_{j}-\pi_{j}+z_{j}\right)$ for each strategy combination in matrix form as follows;

Agent $j$

\begin{tabular}{|c|c|c|c|c|}
\hline & 0 & $\{0, \eta\}$ & $R$ & $2 R$ \\
\hline 0 & $\{R, R\}$ & $\{2 \mathrm{R}+\varepsilon, \gamma\}$ & $\{2 R, R\}$ & $\{\gamma, R-\varepsilon\}$ \\
\hline$\{0, \eta\}$ & $\{\gamma, 2 R+\varepsilon\}$ & $\{\gamma, \gamma\}$ & $\{\gamma, \gamma+R\}$ & $\{0,2 R\}$ \\
\hline$R$ & $\{R, 2 R\}$ & $\{\gamma+R, \gamma\}$ & $\{R, R\}$ & $\{-\varepsilon, \gamma+2 R\}$ \\
\hline $2 R$ & $\{R+\varepsilon, \gamma\}$ & $\{2 R, 0\}$ & $\{\gamma+2 R,-\varepsilon\}$ & $\{2 R, 2 R\}$ \\
\hline
\end{tabular}

Figure 4. Matrix of strategy combination. 
Therefore, for four possible states $x=\left\{x_{1}, x_{2}\right\} \in[\{0,0\},\{0, m\},\{m, 0\}$, $\{m, m\}]$, there is a unique Nash equilibrium. For instance, in state $\{0,0\}$ both agent pays nothing and report nothing, in state $\{0, m\}$ and $\{m, 0\}$ the successful agent pays $2 R$ and the unsuccessful agent pays nothing and report $\eta$ to the bank. In the state $\{m, m\}$ both agents repay $R$ to the bank. In equilibrium, each successful agents has an incentive to pay for their peer and all agents will truthfully report $\eta$. In fact, in Nash equilibrium the punishment is not imposed in three states namely $\{0, m\},\{m, 0\}$ and $\{m, m\}$. Only state $\{0,0\}$, the bank will punish the agents with a smaller punishment $\{R, R\}$ . In fact, the severe punishment is never occurring in equilibrium. Therefore, cross-reporting mechanism is efficient because the bank will impose a smaller punishment and can increase the borrower's welfare in equilibrium. The result is summarised in Table 2.

Table 2

Nash Equilibrium

\begin{tabular}{ccc}
\hline State $\left(x_{1}, x_{2}\right)$ & Punishment $\left(z_{1}, z_{2}\right)$ & Repayment $\left(\varphi_{p}, \varphi_{2}\right)$ \\
\hline$(0,0)$ & $(\mathrm{R}, \mathrm{R})$ & $(0,0)$ \\
$(0, \mathrm{~m})$ & $(0,0)$ & $(0,2 \mathrm{R})$ \\
$(\mathrm{m}, 0)$ & $(0,0)$ & $(2 \mathrm{R}, 0)$ \\
$(\mathrm{m}, \mathrm{m})$ & $(0,0)$ & $(\mathrm{R}, \mathrm{R})$ \\
\hline
\end{tabular}

\section{Without Cross-Reporting}

Without cross-reporting, the bank can design a mechanism that encourages the collaboration among the group members. Meanwhile, for each possible state, the bank has to impose harsh punishments on the borrowers in equilibrium even when he/she is unlucky and defaults involuntarily. This is a deadweight loss. Even though the bank has unlimited enforcement ability (extremely harsh punishment), the bank is unable to distinguish between strategic and involuntary default. In this situation, the lender is unable to verify the state of the project. As a result, the lender would over-punish the 
borrowers under both defaults. Therefore, the successful borrower has an incentive to repay the unsuccessful borrower. So, without cross-reporting, it is not efficient because the punishment and the deadweight loss is also higher. For instance, if only one agent was successful but that agent refuses to pay anything, it looks to the bank as a state $(0,0)$. Consequently, each agent must suffer a punishment at least $2 R$ in a state $(0,0)$. This is inefficient because, under crossreporting, for state $(0,0)$ each agent's punishment is only $(R, R)$. Therefore, the cross-reporting mechanism is efficient because not only the bank will impose a lowest punishment and reduce the deadweight loss, but it also encourages borrowers to share the risk and help each other at the lowest possible cost.

On the other hand, without cross-reporting the bank can undertake auditing or verify the state of the project and punish accordingly. The bank would punish only when the borrower is lying about the state of the project. Therefore, the mechanism designer objective is to audit with sufficient frequency to discourage the borrower from lying. Consequently, in equilibrium to avoid the punishment from the bank, all borrowers simultaneously and truthfully reveal their types about the state of the project. Ghatak and Guinnane (1999) in the costly state verification mode ${ }^{21}$, showed that in equilibrium the bank charged lower interest rates under joint liability than individual lending. In addition, the borrowers under joint liability are audited with a lower probability than individual lending. With a lower probability of auditing, the lender has experienced a lower auditing cost and subsequently transfers this benefit to the borrowers in joint liability contract by charging lower interest rates. Therefore, joint liability lending is more efficient than individual lending. This is because joint liability can encourage the borrower to tell the truth with a lower probability of auditing. Hence, with lower expected auditing costs, there is a greater social surplus, which is shared between the borrower and bank according to their relative bargaining strength.

\section{Other Lending Mechanisms}

Besides the joint liability and cross-reporting mechanisms, other lending mechanisms should be considered by the bank such as sequential financing, regularly repayment schedule, and dynamic incentive. For example, Jain and Mansuri (2003) found that tightly structure instalment (regularly repayment schedule) is a very important mechanism in order to avoid the moral hazard problem and can improve fiscal discipline among the borrowers. In fact this

20 IJMS 17 (2), 1-26 (2010) 
mechanism is also essential in monitoring borrower actions (screening and early warning system to the lender), allows the borrowers to repay in manageable bits, and give incentives to the borrowers to diversify income sources. For instance, the borrowers from Grameen Bank are required to repay their loan in weekly instalments over a year, with the first instalment due immediately. Meanwhile, according to Jain and Mansuri (2003) the regular repayment induces the borrowers to borrow from informal money lenders in order to repay the microfinance lender.

Sequential financing is also an important mechanism to minimise the moral hazard problem. In sequential lending, one borrower gets the loan while the second borrower is waiting for the loan. Under this mechanism, the second borrower only gets the loan if the first borrower succeeds to repay the entire loan (principal plus interest rates). Chowdhury (2005) found that with sequential financing, it generates a positive level of monitoring by the borrowers. In fact, if sequential financing is involved with joint liability, it can generate higher repayment rates and can minimise the moral hazard problem.

Dynamic incentives such as progressive lending is also an important mechanism for the microfinance lender. If the group members succeed to repay the entire instalments on schedule, their loans quickly increase in size. This kind of incentive will encourage the borrowers to have a good repayment record. Specifically, progressive lending schemes increase the opportunity cost of non-repayment and thereby discourage strategic default even further (Armendariz \& Morduch, 2007).

\section{Summary and Conclusion}

This essay investigates how the MFIs design the loan contract in order to achieve the social welfare among the poor borrowers under the existence of private (asymmetric) information. Since most of the MFIs are non-profit organisations, thus designing an optimal loan contract is crucial in order to maximise the borrowers social welfare and at the same time to minimise or avoid the problem of asymmetric information among the borrowers. Therefore, the joint liability theory has been analysed by using the main problem in the credit market, namely adverse selection. Based on joint liability theory, it was clearly stated that this mechanism is better than individual lending in terms of high repayment rates, lower interest rates, and increase social welfare. Joint liability is also a good mechanism to minimise or 
avoid the adverse selection problem through peer selection and peer screening.

The cross-reporting mechanism is also important for lenders in order to minimise the problem of asymmetric information in the credit market. This lending mechanism is also efficient because the tendency of the borrower to be truthful-telling about the state of the project and subsequently can minimise deadweight loss (punishment) among borrowers. In contrast, withoutcross-reporting, thelending mechanism is inefficient because the borrower will be imposed harsh punishment from the bank. On the other hand, other lending mechanisms such as regular repayment schedules, sequential financing, and progressive lending are also essential to the microfinance in order to minimise the problem of private information in the credit market. Therefore, the various combinations of lending mechanisms are pivotal for the MFIs in minimising the adverse selection problem in the credit market.

In addition, besides the adverse selection problem, future research should focus on other problems in the credit market such as moral hazard, costly state verification, and enforcement in the MFIs environment through an empirical or theoretical study. In fact, further studies should also focus on the effectiveness of various lending mechanisms and how these mechanisms operate together through experimental approach and systematic evaluation. Finally, it is also crucial to identify what really drives the MFIs performance and an assessment of the impact of MFIs lending to the poor borrower.

\section{Endnotes}

1. In 2006, Muhammad Yunus and Grameen Bank have been awarded the Nobel Peace Prize for their contributions to create economic, social development, and eradicating the poverty problem.

2. According to the survey conducted by Microfinance Information Exchange (MIX), in 2004 there are 1000 to 2500 MFIs around the world which serve some 67.6 million clients. More than half of them live below the poverty line. (Sengupta \& Aubuchon, 2008).

3. Today, the Grameen Bank has been replicated in 30 countries from east Timor to Bosnia. Group lending programmes also operate in 30 of the 50 states in the Unites States (Armendariz \& Morduch, 2007).

22 IJMS 17 (2), 1-26 (2010) 
4. In 2002, the Grameen Bank had shifted to a new system known as Grameen II, which discards the joint liability scheme and moves to the individual loans.

5. A comprehensive review of the microfinance literature can be found from Brau and Woller (2004).

6. The Grameen Bank is a non-profit organisation, which charges interest rates (20\% per year) below market rates and other MFIs in order to promote social equity. Meanwhile, not all MFIs are non-profit organisations. MFIs like Banco Sol of Bolivia operate with the intent to maximise profit.

7. A detailed discussion about the microfinance revolution around the world can be found from Hassan (2002).

8. Recent theoretical studies of microfinance can be found from Stiglitz (1990), Besley and Coate (1995), Ghatak and Guinnane (1999), and Ghatak (1999, 2000).

9. Ghatak and Guinnane (1999) provided an excellent theoretical survey about how the joint liability mechanism can solve the problem of adverse selection, moral hazard, costly state verification, and enforcement.

10. Townsend (2003) provided an excellent theoretical survey about microcredit and mechanism design.

11. By December 2007, the Grameen Bank had 7, 411, 229 members organised into 1, 168, 840 groups in 80,678 villages (centres). Therefore, on averages, there were 92 individuals per village and 14.5 groups per village. The female is the dominant members which contributed $97 \%$ of the total members. In addition, since the establishment of Grameen Bank in 1976 until 2007, the bank has a cumulative disbursement (for all loans) by an amount of US \$ 6, 685.51 million at 2, 481 Grameen Bank branches. The data were taken from Grameen Bank 2007. See www.grameeninfor.org for detail.

12. The lending pattern that is practised in Grameen Bank is known as 2:2:1 staggering.

13. This also refers to the agency problems due to the asymmetric information, where the principal is unable to observe the agent's type, such as project riskiness, effort, and the profit. 
14. Stiglitz and Weiss (1981) had pioneered the adverse selection model.

15. A detailed review about the joint liability theory can be found in Ghatak and Guinnane (1999), and Ghatak (1999).

16. $R$ is the interest rates on the loan if the borrower succeeds and $Q$ is the additional joint liability payment which is incurred if the borrower succeeds but her peer fails.

17. Under positive assortative matching, the expected payoff of borrower $i$ under joint liability contract is $\{R, Q\}$ is $U_{i \dot{i}}(R, Q)=p_{i} x_{i}-\left\lfloor p_{i} R+p_{i}\left(1-p_{i}\right) Q\right\rfloor$

18. For a pooling contract $\{\hat{R}, \hat{Q}\}$, the zero-profit constraint requires the bank to break even on the average loan such as $\theta\left[R+Q\left(1-p_{r}\right)\right] p_{r}+(1-\theta)\left[R+Q\left(1-p_{S}\right)\right] p_{S} \geq \rho$.

19. Cross-reporting mechanism has been extensively studied in the implementation literature. For example see Maskin and Sjostrom (2001) for a recent survey.

20. The message is interpreted as a statement about how much the other agent $(j \neq i)$ should repay.

21. Townsend (1979) is a pioneer of optimal contract in competitive market with costly state verification.

\section{References}

Armendariz, B., \& Gollier, C. (2000). Peer group formation as an adverse selection model. The Economic Journal, 110, 632-642.

Armendariz, B., \& Morduch, J. (2000). Microfinance beyond group lending. Economics of Transition, 8, 401-420.

Armendariz, B., \& Morduch, J. (2007). The economics of microfinance. The MIT Press: Cambridge.

Banerjee, A., Besley, T., \& Guinnane, T. (1994). Thy neighbour's keeper: The design of a credit cooperative with theory and a test. Quarterly Journal of Economics, 109, 491-515.

Besley, T. J., \& Coate, S. (1995). Group lending, repayment incentives and social collateral. Journal of Development Economics, 46(1), $1-18$.

24 IJMS 17 (2), 1-26 (2010) 
Bond, P., \& Krishnamurthy, A. (2002). Regulating exclusion from financial markets. Mimeo: Northwestern University.

Brau, C. J., \& Woller, M. G. (2004). Microfinance: A comprehensive review of the existing literature. Journal of Entrepreneurial Finance and Business Venture, 9(1), 1-26.

Chowdhury, P. R. (2005). Group-lending: Sequential financing, lender monitoring and joint liability. Journal of Development Economics, $77,415-439$.

Conning, J. (2000). Monitoring by delegates or by peers? Joint liability loans under moral hazard. Mimeo: William College.

Ghatak, M. (1999). Group lending, local information, and peer selection. Journal of Development Economics, 60, 27-50.

Ghatak, M. (2000). Screening by company you keep: Joint liability lending and peer selection effect. The Economic Journal, 110 (465), 601-631.

Ghatak, M., \& Guinnane, T. W. (1999). The economics of lending with joint liability: Theory and practice. Journal of Development Economies, 60, 195-228.

Hassan, M. K. (2002). The microfinance revolution and the Grameen Bank experience in Bangladesh. Financial Markets Institutions $\mathcal{E}$ Instruments, 11(3), 205-265.

Jain, S., \& Mansuri, G. (2003). A little at a time: The use of regularly scheduled repayments in microfinance programmes. Journal of Development Economics, 72, 253-279.

Laffont, J-J., \& N'Guessan, T. (2000). Group lending with adverse selection. European Economic Review, 44, 773-784.

Maskin, E., \& Sjostrom, T. (2001). Implementation theory. In K. Arrow, A. Sen \& K. Suzumura (Eds.), Handbook of social choice theory, 1, North-Holland.

Morduch , J. (1999). The microfinance promise. Journal of Economic Literature, 37(4),1569-1614.

Rai, S. A., \& Sjostrom, T. (2004). Is Grameen lending efficient? Repayment incentives and insurance in village economies. Review of Economic Studies, 71(1), 217-234.

Sengupta, R., \& Aubuchon, C. P. (2008). The microfinance revolution: An overview. Federal Reserves Bank of St. Louis, Review, 90(1), 9-30.

Stiglitz, J. E. (1990). Peer monitoring and credit markets. The World Bank Economic Review, 4(3), 351-366.

Stiglitz, J. E., \& Weiss, A. (1981). Credit rationing in markets with imperfect information. American Economic Review, 71 (3), 393410.

Townsend, R. M. (1979). Optimal contracts and competitive markets with costly state verification. Journal of Economics Theory, 21(2), 265-293. 
Townsend, R. M. (2003). Microcredit and mechanism design. Journal of the European Economic Association, 1(2-3), 468-477.

Yunus, M. (1999). The Grameen Bank. Scientific American, November, 144-119.

26 IJMS 17 (2), 1-26 (2010) 